Salmi, J. (2009) The Challenge of Establisbing World-Class Universities. World Bank Publications. $116 \mathrm{p}$.

Scherrer C. (2005) GATS: Long-term Strategy for the Commodification of Education. Review of International Political Economy, vol. 12, no 3, pp. 484-510.

Submission date: 15.09.2019.

Гусейн-заде Рена Гаджиага кызы - аспирант кафедры гуманитарных и общественных наук МИРЭА - Российский технологический университет. ААрес: 119454, Россия, г. Москва, пр. Вернадского, д. 78. Тел.: +7 (499) 215-65-65. Эл. адрес: rena.guseynzade@mail.ru. Научный руководитель - А-р социол. наук, проф. А. А. Аеревянченко.

Аеревянченко Александр Алексеевич - доктор социологических наук, профессор, профессор кафедры социологии Московского гуманитарного университета. Адрес: 111395, Россия, г. Москва, ул. Юности, д. 5. Тел.: +7 (499) 374-51-51. Эл. адрес: a_der@km.ru

Guseyn-Zade Rena Gadzhiaga kyzy, Postgraduate Student, Department of the Humanities and Social Sciences, MIREA - Russian Technological University. Postal address: 78, Vernadskogo Ave., Moscow, Russian Federation, 119571. Tel.: +7 (499) 215-65-65. E-mail: rena.guseynzade@mail.ru Scientific Adviser - A. A. Derevyanchenko, Doctor of Sociology, Professor.

Derevyanchenko Aleksandr Alekseyevich, Doctor of Sociology, Professor, Professor, Department of Sociology, Moscow University for the Humanities. Postal address: 5, Yunosti St., Moscow, Russian Federation, 111395. Tel.: +7 (499) 374-51-51. E-mail: a_der@km.ru

DOI: $10.17805 / z p u .2019 .4 .5$

\title{
Имитации в высшей школе: следствие модернизации?
}

\author{
Н. А. СЕЛИВЕРСтОВА \\ МОСКОВСКИЙ ГУМАНИТАРНЫЙ УНИВЕРСИТЕТ
}

В статье анализируется проблема имитаций в высшей школе на материалах интервьюирования преподавателей и студентов московских университетов (октябрь 2018 - май 2019 г.). Рассматриваются оценки рисков и субъективные смыслы имитации образовательных практик. Субъективные смыслы имитации образовательных практик, разделяемые преподавателями, обнаруживают понимание однозначно негативного характера имитаций («имитация - это развал высшего образования», «неправильные, нехорошие, нечестные действия», «имитация образовательной деятельности действует разрушительно на преподавателя»). Что касается студентов, то они, осознавая негативную природу имитации образовательных практик, дополняют субъективные смыслы данного явления признанием некоторых его выгод и одновременно бессмысленности в долгосрочной перспективе.

Преподаватели определяют магистратуру как уровень высшего образования, для которого в большей степени характерны различные имитации (реализация образовательных программ исходя из кадровых возможностей вуза и его основного профиля, что приводит к уменьшению доли дисциплин, формирующих общепрофессиональные и профессиональные компетенции; нарушение механизма преемственности между программами магистратуры и бакалавриата, отсутствие курсов выравнивания, продвинутых курсов и т. д.). В связи с проблемой имитаций в высшей школе рассмотрено отношение основ- 
ных участников образовательного процесса к заочной и дистанционной формам высшего образования.

Автор делает вывод о глубине проблемы имитаций в высшей школе, разнообразии их форм; выделяет условия, провоцирующие имитации на уровне университетов, имитации рассматриваются, в том числе, как следствие модернизации высшей школы.

Ключевые слова: имитация; высшая школа; образовательные практики; имитации образовательных практик; модернизация системы образования; магистратура; заочная форма обучения; дистанционное образование; университет; преподаватель; студент

\section{ВВЕАЕНИЕ}

$\Pi$ роблемы современной российской высшей школы активно обсуждаются ее преподавателями. В многочисленных открытых письмах представителей профессорско-преподавательского состава ${ }^{1}$ содержится анализ состояния образовательной, научно-исследовательской, воспитательной деятельности конкретных российских университетов, а также проводимой ими политики в отношении преподавателей и студентов. Авторы данных писем обоснованно формулируют проблемы на уровне системы высшего образования (снижение качества высшего образования, его коммерциализация, недостаточное финансирование вузов, перманентное изменение федеральных государственных образовательных стандартов, влекущее за собой разработку новых образовательных программ, а значит, учебных планов, рабочих программ дисциплин, учебно-методических рекомендаций и т. А.; несоответствие заработной платы преподавателей объему нагрузки и растущей интенсивности труда; отсутствие у преподавателя возможности реального повышения квалификации из-за высокой нагрузки; эмоциональное выгорание и т. А.), университетов (неудовлетворительное состояние материально-технической базы). В неполном перечне проблем просматриваются обстоятельства, которые ведут к «припискам», «отпискам», фальсификациям, фикциям, лжи, симуляциям в российской высшей школе. Актуальность исследования различных подмен реальной образовательной и научно-исследовательской деятельности преподавателями и студентами подтверждается и тем фактом, что ученые НИУ «Высшая школа» с 2011 г. анализируют «практики нечестного поведения» и «академическое мошенничество» в российских университетах: списывание, плагиат, преАставление чужих работ как своих, в том числе скачанных из Интернета (Рудаков, Рощина, Битокова, 2019).

Однако остаются вопросы: как понимают ситуации различных имитаций основные участники образовательного процесса: преподаватели и студенты? Как они относятся к ним? Какие смыслы вкладывают в имитации образовательных практик? Какие выделяют риски имитаций? Как относятся к заочному и дистанционному образованию? Иначе говоря, как видится и оценивается ситуация изнутри. Именно поэтому объектом исследования стали преподаватели и студенты московских университетов.

Цель данной статьи заключается в том, чтобы: а) рассмотреть на материалах полустандартизированного интервью проблему имитаций в системе высшего образования, а также другие противоречия, трудности образовательного процесса, связанные с модернизацией содержания и структуры высшего образования; б) ответить на вопрос, насколько распространение имитации образовательных практик связано с модернизацией системы российского высшего образования.

Фокус исследования был направлен на участников образовательного процесса: преподавателей и студентов университетов социально-гуманитарных направлений г. Москвы. Стаж преподавательской деятельности информантов-преподавателей со- 
ставил от 10 до 34 лет. Из числа студентов к участию в исследовании были приглашены обучающиеся четвертых курсов бакалавриата и первых курсов магистратуры. Информанты из обеих групп представили государственные и негосударственные университеты. Было проанализировано по 10 завершенных интервью преподавателей и студентов 2 . В группе преподавателей - 6 женщин и 4 мужчины, студентов - соответственно 5 и 5 .

Метод исследования - «интервью-гайд». В данной статье представлен анализ материалов интервью на следующие темы гайда: отношение к заочной и дистанционной формам высшего образования; оценка рисков имитации образовательных практик $(\mathrm{OП})^{3}$. В процессе анализа стало возможным выделение отдельных подтем: имитации в магистратуре и субъективные смыслы имитации образовательных практик. Интервью проводилось по технологии Б. Аокторова посредством электронной почты (Аокторов, 2016: Электронный ресурс) в период с октября 2018 по май 2019 г. Объем текстов интервью преподавателей варьируется от 8442 знаков до 25850 знаков; студентов - от 8870 знаков до 19238 знаков.

\section{ИНСТРУМЕНТ ПОИСКА НОВОГО ЭМПИРИЧЕСКОГО ЗНАНИЯ}

Понятия «имитация», «симуляция», «симулякр» в связи с обличением «мира сущностей» и «мира видимостей» использовались И. Кантом и Г. Гегелем. Более того, еще Платон был занят отделением «истинного» от «ложного» (Аелез, 1998: 225-226). Исследователи проблематики имитаций из ряда менее удаленных от нас по времени включали в анализ условия, продуцирующие данное явление. Так, Ж. Аелез и Ж. Бодрияр акцентировали внимание на девиантной или даже делинквентной природе имитации, так как результат процесса обеспечивается хитростью, различными уловками (Аелез, 1998: 230; Бодрияр, 2015: 5).

Феномен имитации связывает с социальными пороками и Ж. Т. Тощенко. В результате анализа современной реальности он делает вывод о масштабном процессе имитации - подмены деятельности во всех сферах жизнедеятельности общества, на всех уровнях. Как первичные им рассматриваются имитации в сфере политики и экономики, имитации в социальной и духовной жизни в данном контексте выступают следствием (Тощенко, 2015: 315). Определяя причины имитации, Ж. Т. Тощенко анализирует данный процесс как результат осознанной и неосознанной деятельности. Обеспечиваются искусственные условия для процессов и явлений, предназначенных для корыстных, мнимо значимых корпоративных или групповых целей (там же: 315-316). В свою очередь, подобная ситуация свидетельствует о стихийном развитии государства, общества, его социальных институтов. В качестве основной базы имитации называется отсутствие четкой стратегической цели развития общества, его сфер, социальных институтов, организаций, процессов (там же: 316). Насколько данный постулат применим к сфере высшего образования, отчасти можно будет судить по результатам анализа материалов интервьюирования.

Ж. Бодрияр подчеркивал различие между имитацией и простым притворством. В имитации сложно отличить «реальное» и «мнимое» (Бодрияр, 2015: 7-8). Имитация - это подмена реальности с использованием признанных, объективных знаковсредств этой реальности. Именно в этом значении и используется понятие «имитация » применительно к высшей школе.

Под имитацией образовательных практик в данной статье понимается подмена действий, с одной стороны, преподавателем университета по передаче комплекса зна- 
ний, умений, навыков и социальных ценностей, идеалов, культурных образцов студентам формальным воспроизведением процедур, демонстрацией соблюдения установленного хода образовательного процесса, с другой стороны, студентом по освоению названного комплекса. Приведенное определение является скорректированным вариантом интерпретации понятия, данной мною ранее (Селиверстова, 2019). По своему характеру эти действия могут быть осознанными практиками, связанными с планомерной деятельностью, и опривыченными.

\section{ОЦЕНКА РИСКОВ ИМИТАЦИИ ОБРАЗОВАТЕАЬНЫХ ПРАКТИК}

Преподавателями и студентами были названы следующие формы имитации образовательных практик: чтение лекции без включения студентов в образовательный процесс ( «себе под нос»); прием экзамена или зачета по непрочитанному курсу; «непроверенные задания», которые даются вместо аудиторных занятий преподавателем, переключившимся на выполнение административных функций; замена лекционного или практического занятия рассказами о жизни (своей или своих знакомых), путешествиях, обучение каким-либо навыкам, не имеющим отношения к преподаваемому курсу (например, техникам дыхательной гимнастики); проведение семинарских и практических занятий в формате докладов, чтения рефератов (сегодня это превращается в поиск студентом нужного файла в Интернете - иногда на самом занятии, часто его первое и, может быть, единственное прочтение с мобильного телефона); «деление» вопросов семинарского занятия между студентами, когда каждый готовит только «свой» вопрос, а остальная часть студенческой аудитории выступает в роли слушателей; списывание на контрольных работах и при сдаче зачетов и экзаменов; представление выполненных на заказ курсовых и выпускных квалификационных работ; имитация контроля знаний (имитация текущей, промежуточной и, как закономерный результат, итоговой аттестации). Важно то, что студентами было выделено тестирование как форма имитации контроля знаний.

Теперь об оценке рисков имитации образовательных практик.

Преподаватели оценили риски имитации образовательных практик следующим образом: снижение уровня профессионализма выпускников вузов; отъезд наиболее мотивированных, хорошо подготовленных абитуриентов на учебу за границу, в свою очередь, поток из-за границы молодежи, рассчитывающей получить в России диплом, а не образование; эмоциональное выгорание преподавателей с относительно небольшим стажем работы; трудоустройство выпускников социальных и гуманитарных направлений в сфере управления (проблема в том, что их габитус включает предрасположенность к имитационным практикам, тем самым «добавляет хаотичность, нестабильность, непродуманность» в управлении); деградация профессорско-преподавательского состава, потому что имитации ведут к потере самоуважения, профессионализма и творческого потенциала, столь необходимых для работы со студентами; отклоняющаяся профессиональная социализация молодых преподавателей, Аля которых имитация становится нормой, формирование габитуса имитатора. Студенты дополнили данный ряд такими определениями, как дискредитация научного сообщества, которая заключается в потере авторитета и престижа статуса ученого/преподавателя вуза; неконкурентоспособность выпускаемых бакалавров, специалистов, магистров на рынке труда; подпитка теневой экономики (частное репетиторство и написание учебных и квалификационных работ за вознаграждение); коррумпированность сферы образования. 
Репутационные риски были выделены в обеих группах интервьюируемых: снижение ценности высшего образования и утрата положительного имиджа некоторыми университетами.

Субъективные смыслы имитации образовательных практик, которые выражены преподавателями, носят однозначно негативный характер. Они определяются по отношению к высшему образованию ( «имитация - это развал высшего образования», «неправильные, нехорошие, нечестные действия») и себе («имитация образовательной деятельности действует разрушительно на преподавателя»). Субъективные смыслы имитации образовательных практик, выраженные студентами ${ }^{4}$, содержат как понимание проблемы («имитация страшна прежде всего тем, что у немотивированных людей есть потребность только в получении диплома, а не самих знаний, а значит, ее практически не исправить»), так и отсутствие однозначной отрицательной оценки ( «возможность имитации образовательных практик имеет свои плюсы как для студента, так и для преподавателя. Однако в долгосрочной перспективе это бессмысленно»).

\section{МАГИСТРАТУРА - ПРОСТРАНСТВО АИЯ ИМИТАЦИЙ?}

Опрошенные преподаватели и студенты представляют направления подготовки, реализуемые по трем уровням: бакалавриат, магистратура, аспирантура ${ }^{5}$. В интервью с преподавателями рефреном возникала тема имитаций в магистратуре: «...там имитаций больше, чем в бакалавриате».

Итак, какие это имитации и почему они существуют как практики? Во-первых, это имитации на уровне отдельных университетов, реализующих образовательные программы исходя из кадровых возможностей вуза, а значит, и его основного профиля. Это приводит к тому, что в учебном плане, например направления «Социология», доля дисциплин иностранного языка или курсов по менеджменту нелогично увеличена за счет дисциплин, формирующих общепрофессиональные и профессиональные компетенции. Аанный факт уже описан (Зырянов, 2017: 229). Почему это возможно? Это позволяют гибкие рамки образовательного стандарта. K тому же встречаются расхождения между названиями дисциплин и их содержанием. Зачем это нужно вузу? Аля поддержания статуса университета.

Во-вторых, прием в магистратуру абитуриентов без квалификации бакалавра по направлению подготовки магистратуры. Эта практика особенно беспокоит преподавателей, участвующих в реализации образовательных программ по направлению «Психология» и «Психолого-педагогическое образование»: «...их невозможно за два года обучить методам диагностики, исследования, обработки и анализа данных. Они получают диплом магистров психологии, который практически ничем не подmвержден» ${ }^{6}$ (муж., канд. наук, стаж пед. деят-ти - 12 л., негос. ун-т). Социологов в подобном случае тревожит отсутствие курсов выравнивания и проблема чтения «продвинутых» курсов в магистратуре. Продвинутых курсов в некоторых вузах просто нет (речь идет о федеральном университете). Почему? Потому что есть проблема кадров и их усталости: «...с продвинутылии курсами тоже сложно. Читают у магистров часто профессора, они люди немолодые, разрабатывать новые курсы не хотлт / не могут. Часто магистратура - это повторение курсов, которые читались бакалаврам. Обычно, если магистр учился у нас на бакалавриате, то ему почти все ставят автоматом, так как нового в читаемьх курсах практически нет. ...Bот у нас профессор говорит, ито у него у одних и тех же студентов три похожих кур- 
са. Так он на них рассказывает одно и то же, не заморачиваясь... Говорит об этом открыто коллегам. А что, деньги зарабатывать надо, а напрягаться уже не сильно хочется. Мы почти все уже пенсионеры » (жен., А-р наук, стаж пед. деят-ти - 27 лет, гос. ун-т).

Что касается курсов «выравнивания» в магистратуре, мне известно, что в некоторых университетах они реализуются, например в НИУ «Высшая школа экономики». Однако и это - не решение проблемы. Период «подтягивания» студентов, не имеющих квалификации бакалавра по направлению магистратуры, - потерянное время Аля тех студентов, кто имеет данную квалификацию.

Однако справедливости ради надо заметить, что и преподаватели, и студенты в унисон говорят о чрезмерной загруженности преподавателя как важном условии различного рода имитаций. В этой цепи причинно-следственных отношений возникают ситуации, по крайней мере в негосударственном вузе, когда преподаватель читает по 10 и более курсов: «как преподаватель, у которого в нагрузке стоит больше 10 дисииплин, я понимаю, что и физически, и интеллектуально я не могу погрузиться в изучение каждой из них достаточно глубоко...» (жен., канд. наук, стаж пед. деят-ти 10 л., негос. ун-т). И государственные вузы к этому близки: «...наш ректор заявил, что универ берет курс на преподавателей-универсалов. Значит, при ньнешней структуре нагрузки каждьй препод должен будет читать до 10 разньх курсов, а мьь можем сделать это качественно? Мь хорошо знаем свой кусок, а обо всем остальном ведь уже не хорошо... А нам говорят, читайте все подряд. А качество падает. Еще один источник имитаций» (жен., А-р наук, стаж пед. деят-ти - 27 л., гос. ун-т).

По ходу замечу, что негативных следствий увеличения нагрузки преподавателей более чем достаточно. В этом ряду неравномерное распределение нагрузки по семестрам (преподаватель не может это регулировать): «... моя нагрузка 900 часов, и почти все “горло"... а когда в том (осеннем) семестре работала пять раз в неделю, думала только о том, как бы выжить..." (жен., А-р наук, стаж пед. деят-ти - 27 л., гос. ун-т).

Проблемы с составлением расписания, когда преподаватель просто не помещается в его сетку, вероятно, самые незначительные.

Как серьезная проблема, имеющая системный характер, выделяется противоречивое отношение молодежи к обучению в магистратуре. С одной стороны, диплом магистра создает эффект завершенного высшего образования и часто дает возможность получить еще одно высшее образование, с другой - высшее образование (квалификация бакалавра) уже есть, и особо стараться не хочется. «...B магистратуре доля тех, кто учится “как бы” значительно возрастает, $u$ от семестра к семестру только растет, ни оченки, ни знания уже не волнуют, задача только одна - получить диплом. Боюсь, что здесь пропориия выглядит как 20/80 в пользу имитаторов. И это проблема. Магистранть - это уже люди с дипломом о высшем образовании, они на эти же $80 \%$ уже где-то как-то работают, а учатся по остаточному приниипу. Может быть, это проблема столичного университета с очень большим приемом в магистратуру... Если прием был бы только 20 человек, то вероятность выбрать мотивированных на учебу, возможно, была бы выше» (муж., канд. наук, стаж пед. деят-ти - 34 г., гос. ун-т). Зеркально отражают ситуацию с приемом в магистратуру интервью со студентами также государственного вуза. «...Я в магистратуре завела разговор с одногруппником относительно теорий, а он этих фамилии $b$ жизни не сльшал. Я говорю: “Здрасте, приехали! Эти теории даже в вопросах для вступи- 
тельного экзамена были”. На что он мне ответил, что он читал ровно те вопросьи, которье ему попались на экзамене, и читал он их тоже только пока списывал" (жен., первый курс магистратуры, гос. ун-т).

Отдельно студентами маркируется проблема обеспеченности курсов учебной и учебно-методической литературой. Неожиданный результат, как минимум, если учесть, что преподаватели тратят бо́льшую часть внеаудиторной работы на создание и регулярную переделку учебно-методических материалов, одновременно корректируя списки основной и дополнительной литературы. О чем это свидетельствует? О том, что учебно-методическая деятельность преподавателя и его работа в аудитории существуют в некой параллели. Это подтвердили в своих интервью преподаватели либо на собственном опыте, либо на опыте коллег.

Наиболее яркая иллюстрация - фрагмент из интервью студентки государственного вуза, которая вспоминает и опыт обучения в бакалавриате: «...По каким-то дисциплинам я учебники покупала сама (основь и история сочиологии, испанский, экономика организачий). А в остальном на вопрос об учебниках ответ был один: "Ищите сами в Интернете”. В лучшем случае говорили фамилию автора и название учебника. Многие учебники и литературу просто так не найдешь, надо заказьвать, покупать и т. д. В итоге приходится довольствоваться сайтами типа Википедии и студфайлс. А ссылаться на них при ответе - не комильро. А учат студенть именно по этим ресурсам. В лучшем случае читают статьи и аннотации к статьям nо теме» (жен., первый курс магистратуры, гос. ун-т).

Отсылка студентов к Интернету без конкретных рекомендаций, безусловно, провокация имитации подготовки студентов к семинарским/практическим занятиям. В то же время есть свидетельства преподавателей, что студенты не следуют их рекомендациям и пользуются доступными ресурсами Интернета. Проблема обеспеченности учебниками, в частности по социологии, подтверждается анализом статистических данных выпуска учебной литературы и выборочным качественным анализом текстов некоторых учебников (Селиверстова, 2015).

\section{ЗАОЧНАЯ И АИСТАНЦИОННАЯ ФОРМЫ ВЫСШЕГО ОБРАЗОВАНИЯ В КОНТЕКСТЕ ИМИТАЦИЙ}

Университеты с особым статусом не ведут прием абитуриентов на заочную форму обучения: МГУ имени М. В. Аомоносова - с 2013 г., СПбГУ - с 2010 г. Среди тех, кто отказался от реализации образовательных программ по заочной форме, и некоторые другие региональные вузы. Основная причина - низкое качество образования на заочном отделении 7 . Высокая доля студентов-заочников или их преобладание в структуре обучающихся университета рассматривается в образовательном пространстве как негативная характеристика репутации вуза. Что касается дистанционной формы высшего образования, то возникает вопрос: это цифровая альтернатива заочному обучению или принципиально новая форма высшего образования? И не являются ли заочная и дистанционная формы высшего образования широким полем для имитации?

Преподаватели подчеркивают, что заочная и дистанционная формы обучения в вузе возможны для ограниченного перечня направлений и специальностей. В среде преподавателей-психологов подготовка бакалавров и магистров психологии по заочной форме обучения не находит понимания. Известно, что ряд вузов не реализовывал образовательные программы по направлению «Психология» на заочной форме обуче- 
ния. По мнению преподавателей, заочная форма обучения на направлениях «Социология» и «Психолого-педагогическое образование» имеет право на реализацию, если она предназначена для работающих по специальности людей и (или) реализуется в формате субботних-воскресных занятий. В ином случае заочная форма - это имитация. Аистанционное образование рассматривается как инструмент, который может быть применен вполне результативно не только в части организации, определения заданий и их выполнения, но и в части идентификации студента, контроля его знаний и навыков. В обратном случае дистанционное образование - высокотехнологичное средство имитации образовательных практик и легитимации выдачи дипломов о высшем образовании.

Существенное замечание относительно реализации образовательной программы по направлению «Социология» в дистанционной форме связано со спецификой знаний об обществе: «Менеджмент считает, что это дешевле будет, чем оплачивать профессуру. Только все в сочиальньх науках быстро устаревает, получится новыми технологиями будем “старье” транслировать» (жен., А-р наук, стаж пед. деят-ти 28 л., гос. ун-т). Есть и крайне негативное восприятие дистанционной формы высшего образования: «Это просто вырождение» (жен., д-р наук, стаж пед. деят-ти - 27 д., гос. ун-т). Распространен акцент на мотивацию, добросовестность и ответственность участников образовательного процесса с обеих сторон как обязательные условия, исключающие имитацию. Есть также акцент на периодическую необходимость непосредственного взаимодействия преподавателей и студентов при реализации дистанционной формы высшего образования: «Я считаю, ито эта форма даже более открыта, так как есть возможность оченить все действия преподавателя. Но семинарские и творческие занятия должнь проводиться при личной встрече с обучающимися» (жен., канд. наук, стаж пед. деят-ти - 10 л., негос. ун-т).

Еще одна проблема, связанная с реализацией дистанционного образования, выделена преподавателями. Это сложность представления лекционного материала, учитывая полипарадигмальность психологии, педагогики и социологии и крайне небольшой объем времени (в интервью речь шла о четырех академических часах). Как представить в этом случае материал лекции, если обращаешься к студентам в записи и непосредственного контакта не предусмотрено? Ориентация на тестирование как форму контроля знаний жестко структурирует лекции и однозначно упрощает материал: «Эти так назыьаемые новые формы препятствуют формированию умения самостоятельно думать, адекватно, критически перерабатьљать информачию, ито есть главное в высшем образовании, на мой взгляд...” (жен., д-р наук, стаж пед. деят-ти 27 л., гос. ун-т).

Студенты также демонстрируют неоднозначное, но несколько более разнообразное и эмоциональное отношение к данным формам высшего образования, чем преподаватели. О заочной форме: «отличный способ», «хороший способ»; о заочной и дистанционной форме: «прекрасный выход», о дистанционном образовании: «это просто формальность для получения корочки». Уточнение связано с тем, что эта форма подходит для организованных людей, обладающих высокой степенью ответственности, способных самостоятельно осваивать знания, в иных случаях - имитация. Та часть студентов, у которых эти формы вызывают скептическое отношение, тоже допускают, что отдельные люди, группы с различными ограничениями возможностей, не обязательно связанных со здоровьем, способны вполне успешно получить знания, приобрести квалификацию. Устойчива мысль о том, что человек должен иметь возможно- 
сти получить высшее образование, не обязательно в формате очного или вечернего обучения, как обеспечение свободы выбора абитуриента. Однозначно отрицательное отношение к заочному и дистанционному образованию выражено в единичном случае: «...заочное и тем более дистаниионное образование не дает нормальных знаний и не является высшим образованием в прямом смысле этого слова» (жен., первый курс магистратуры, гос. ун-т).

Сингулярность отношения студентки, высказанная в формуле: «Аистаниионное (электронное) образование - отличная альтернатива заочной форме обучения» (жен., первый курс магистратуры, негос. ун-т), заслуживает особого внимания своей аргументацией. Аргументация сводится к тому, что опосредованное взаимодействие преподавателя и студента обеспечено на всех этапах изучения дисциплины, что гарантирует открытость процесса, а значит, контроль и объективную оценку. К тому же будущему студенту предоставляется возможность заранее оценить качество обучения. Аобавлю, что это по силам не каждому абитуриенту.

Однако и преподаватели, и студенты отмечают более лояльное, менее требовательное отношение преподавателей к студентам-заочникам, что оценивается негативно. И преподаватели, и студенты преимущество заочного образования в сравнении с дистанционным видят в непосредственном, хотя и минимизированном по объему, взаимодействии преподавателя и студента: «Все-таки хочется общаться с умными людьми не только через Интернет» (жен., четвертый курс бакалавриата, негос. ун-т); «По факту можно самостоятельно изучать то, ито предлагается на программе дистанчионного образования. Ааже на заочной форме обучения общение с преподавателями, хоть и минимально, но есть. Можно вьделить время и подойти к преподавателю и уточнить то, что непонятно, или посоветоваться насчет написания научньх работ. Аистаниионное же обучение такого совсем не предполагает. Мне кажется, в этом нет смысла...» (жен., первый курс магистратуры, гос. ун-т).

Противоречивое отношение к новому - явление типичное для социума. Вероятно, только время позволит взвешенно оценить российское высшее образование в его дистанционной форме.

\section{ВМЕСТО ЗАКАЮЧЕНИЯ}

В материалах интервью и преподавателей, и студентов подчеркивалась мысль: «Не все преподаватели и студенты имитируют». Безусловно, это так. Но насколько же распространены имитации в системе высшего образования? Как уже говорилось, с 2011 г. в формате мониторинга социологами измеряются «практики нечестного поведения» и «академическое мошенничество» в российских университетах: списывание, плагиат, представление чужих работ как своих, в том числе скачанных из Интернета ${ }^{8}$ (Рудаков, Рощина, Битокова, 2019), т. е. исследуются только явные формы имитации, которые имеют отношение к наблюдаемому и оцениваемому результату. Так, по результатам мониторинга, в 2017 г. по сравнению с 2014 г. практики нечестного поведения по некоторым позициям наблюдались чаще. Речь идет о сдаче студентами купленных (написанных на заказ, готовых) письменных работ (2014 г. - 48,3\%, 2017 г. - 54,8\%) или работ, скачанных из Интернета (соответственно 78,1\% и 82,9\%), а также представлении работ студентами старших курсов как своих (соответственно 47,7\% и 58,1\%) (там же: 19). Однако, по данным этого же мониторинга, наметилась и тенденция снижения толерантности преподавателей по отношению к практикам нечестного поведения студентов. 
Многочисленные риски имитации образовательных практик, определенные основными участниками образовательного процесса, сегодня уже не просто прогнозы, некоторые из них подтвердились и представляют реальные потери. Например, обесценивание образования в магистратуре. Системное нарушение механизма преемственности между образовательными программами бакалавриата и магистратуры вкупе с высокой загруженностью преподавателей и другими обстоятельствами создают благоприятные условия для различного рода имитаций. Проблемы обучения в магистратуре носят системный характер, свойственны не только направлениям подготовки, представленным в исследовании (Мотовилов, 2016; Сенашенко, Пыхтина, 2017).

Почему имитации существуют на уровне университетов? Начну с того, что доступность и качество образования в соответствии с мировой практикой достигается за счет «сжатия сети образовательных организаций» (Цели устойчивого развития $\mathrm{OOH}$ и Россия ... , 2016: 181). В период с 2011 по 2016 г. число российских вузов сократилось в 1,3 раза; сжатие сети государственных (муниципальных) вузов происходит несколько медленнее, чем негосударственных (снижение в 1,3 и 1,4 раза соответственно) (там же). Очевидно, что срабатывает закон самосохранения организаций. Кроме того, в существующих условиях реформирования университету иначе не сохранить свой статус. Не претендуя на полноту перечня условий модернизации высшего образования, а также становления его модели, вкдючающей государственные и рыночные механизмы регулирования, провоцирующие имитации, назову некоторые из них. Это механизмы финансирования государственных вузов (подушевое финансирование), федеральные государственные образовательные стандарты, ряд требований которых невыполним при существующем материально-техническом обеспечении университетов, увеличение нагрузки преподавателя и т. д. Проблема инвестиций в высшее образование заключается и в отставании Российской Федерации по госрасходам (в \% к ВВП) по сравнению с другими европейскими странами и в диспропорции бюджетного финансирования по регионам (Плаксий, 2015).

В Концепции Федеральной целевой программы развития образования на 2016-2020 гг. цель его модернизации представлена как «создание механизма устойчивого развития системы образования 10 . Цель модернизации системы образования, безусловно, стратегическая, если вспомнить тезис Ж. Т. Тощенко, но возникает вопрос о способах достижения цели. Что касается нынешнего этапа модернизации, то она направлена, в том числе, на содержание и структуру высшего образования в соответствии с запросами рынка труда. В Концепции Федеральной целевой программы развития образования на 2016-2020 гг. сказано: «Аолжна быть создана система постоянного мониторинга текущих и перспективных потребностей рынка труда в кадрах различной квалификации, в том числе с учетом международных тенденций. В соответствии с этими потребностями предстоит выстроить оптимальную систему профессионального образования, в частности, реальную многоуровневую структуру высшего образования» (курсив мой. - H. С.) $)^{11}$. Аокумент создавался в конце 2014 г. Получается, что разработчикам концепции было ясно, что по большому счету существует видимость многоуровневой структуры высшего образования? В этом контексте имитации в системе российского высшего образования являются не настолько уж и парадоксальным следствием модернизации.

Имитации социальных практик - явление архаичное. Однако масштаб имитаций, их формы зависят от существующих условий, которые могут быть более или менее благоприятными для них. Реформирование любой сферы без достаточных ресур- 
сов - прямой путь к имитациям. Аанные, полученные в процессе интервьюирования, свидетельствуют о глубине проблемы имитаций в высшей школе, разнообразии их форм, о том, что происходит на уровне преподаватель - студент, о процессе, который протекает, как нынче говорят, по умолчанию... обеих сторон.

\section{ПРИМЕЧАНИЯ}

${ }^{1}$ См., напр.: Открытое письмо питерских доцентов министру образования и науки О. Ю. Васильевой [Электронный ресурс]. URL: http://netreforme.org/news/otkryitoe-pismo-piterskihdotsentov-ministru-obrazovaniya-i-nauki-o-yu-vasilevoy/ (дата обращения: 05.05.2019) ; В. Афанасьева Открытое письмо министру образования и науки О. Васильевой. Пять признаков тяжелой болезни [Электронный ресурс]. URL: https://muzobozrenie.ru/vera-afanas-eva-otkry-toepis-mo-ministru-obrazovaniya-rf-ol-ge-vasil-evoj/ (дата обращения: 05.05.2019) ; Письмо профессора ВГУ Иосифа Стернина об изменениях в управлении наукой и образованием в России [Электронный ресурс]. URL: https://philologist.livejournal.com/10921642.htmlhttps://philologist.livejournal.com/10921642.html (дата обращения: 05.05.2019) ; Осейчук В. И. Открытое письмо профессорам России [Электронный ресурс] URL: https://pdsnpsr.ru/news/8910-otkrytoe-pismoprofessoram-rossii_29052019 (дата обращения: 14.08.2019).

2 Кроме того, в анализе учтены и тексты четырех незавершенных интервью с преподавателями и трех - со студентами.

3 Такие темы гайда, как признание факта ситуации «преподаватели как бы учат, студенты как бы учатся», позиционирование себя преподавателями и студентами по отношению к данной ситуации, формы и условия имитации образовательных практик, оценка роста масштабов имитации образовательных практик в связи с развитием Интернета, понимание девиантной/делинквентной природы имитации образовательных практик основными участниками образовательного процесса и их отношение к исследуемому явлению, рассмотрены в другой статье. Она предложена редакции журнала «Социс».

${ }^{4}$ В исследовании принимали участие мотивированные студенты, успевающие на отлично и хорошо, имитирующие образовательные практики фрагментарно. К сожалению, рекрутировать студентов, регулярно практикующих имитацию образовательных практик, не удалось.

5 Проблема подготовки научно-педагогических кадров высшей квалификации (аспирантура) в процессе интервьюирования не затрагивалась.

6 Здесь и далее фрагменты интервью приводятся в редакции информантов.

7 Ивойлова И. Заточить перо. МГУ отказался от заочного отделения [Электронный ресурс]// Российская газета. № 149 (6125) URL: https://rg.ru/2013/07/10/zaochka-site.html (дата обращения: 20.05.2019).

8 Как обычно, в подобных случаях анкета корректируется: неактуальные вопросы и шкалы изымаются, актуальные - включаются. Какие-то практики нечестного поведения стали измерять с 2013-2014 гг.

9 Здесь даны суммы ответов «время от времени» и «часто».

10 Концепция Федеральной целевой программы развития образования на 2016-2020 годы. Утверждена распоряжением Правительства РФ от 29 декабря 2014 г. № 2765-р [Электронный ресурс] // Правительство России. URL: URL: http://static.government.ru/media/files/mlorxf XbbCk.pdf (дата обращения: 20.05.2019).

11 Там же.

\section{СПИСОК АИТЕРАТУРЫ}

Бодрияр, Ж. (2015) Симулякры и симуляция. М. : Издательский дом «ПОСТУМ». 240 с.

Аелез, Ж. (1998) Платон и симулякр // Интенциональность и текстуальность. Философская мысль Франции ХХ века / сост. Е. А. Найман, В. А. Суровцев. Томск : Водолей. 320 с. С. 225-240.

Аокторов, Б. 3. (2016) Современная российская социология: Историко-биографические поиски : в 9 т. [Электронный ресурс]/ Б. З. Аокторов, редактор-консультант А. Н. Алексеев, ре- 
дактор электронного издания Е. И. Григорьева Электрон. текст. дан. (объем 253 Мб). М. : ЦСПиМ. 5901 с. с илл. 1 электрон. опт. диск.

Зырянов, В. В. (2017) Подготовка социологов в университетах России на основе ФГОС 3+ в ракурсе вариативности учебных планов // Высшая школа: опыт, проблемы, перспективы. Материалы X Международной научно-практической конференции : в 2 ч. / науч. ред. В. И. Казаренков. М. : ИзА-во РУАН. Ч. 1.497 с. С. 225-230.

Мотовилов, О. В. (2016) Проблемы подготовки кадров в магистратуре // Высшее образование в России. № 2 (198). С. 38-45.

Плаксий, С.И. (2015) Инвестиции в образование // Знание. Понимание. Умение. №3. С. $18-29$.

Рудаков, В. Н., Рощина, Я. М., Битокова, А. А. (2019) Изменения стратегий, мотиваций и экономического поведения студентов и преподавателей российских вузов. Информационный бюллетень. М. : Национальный исследовательский университет «Высшая школа экономики». 84 с. (Мониторинг экономики образования. № 1 (133)).

Селиверстова, Н. А. (2015) Социологическое образование: обеспеченность учебной литературой и ее качество // Социологические исследования. № 1. С. 128-133.

Селиверстова, Н. А. (2019) Опыт методологической рефлексии исследования имитации образовательных практик в российской высшей школе // II Моисеевские чтения: культура как фактор национальной безопасности России : доклады и материалы Общероссийской (национальной) научной конференции, 26 июня 2019 г. / под ред. А. В. Костиной, В. А. Аукова. М. : ИзА-во Моск. гуманит. ун-та. 520 с. С. 400-404. URL: http://publications.mosgu.ru/index.php/ main/catalog/book/14 (дата обращения: 30.08.2019).

Сенашенко, В. С., Пыхтина, Н. А. (2017) Преемственность бакалавриата и магистратуры: некоторые ключевые проблемы // Высшее образование в России. № 12 (218). С. 13-25.

Тощенко, Ж. Т. (2015) Фантомы российского общества. М. : Центр социального прогнозирования и маркетинга. $668 \mathrm{c.}$

Цели устойчивого развития ООН и Россия. Аоклад о человеческом развитии в Российской Федерации за 2016 г. (2016) / под ред. С. Н. Бобылева и А. М. Григорьева. М. : Аналитический центр при Правительстве РФ. 298 с.

Аата поступления: 30.08.2019 2.

IMITATIONS IN HIGHER SCHOOL: A RESULT OF MODERNISATION?

\section{N. A. Seliverstova \\ MOSCOW UNIVERSITY FOR THE HUMANITIES}

The paper analyses the issue of imitations in higher school and it is based on the materials of interviews with teachers and students at Moscow universities (October 2018 - May 2019). The author considers the risk assessments and subject meanings of educational practices imitations. The subject meanings of educational practices imitations, shared by the teachers, reveal an understanding of the unambiguously negative nature of imitations ("imitations are the collapse of higher education", "wrong, bad, unfair practices", "educational activity imitation has a destructive effect on the teacher"). The students, in their turn, realise the negative nature of educational practices imitation and complete the subject meanings of this phenomenon recognising some of its benefits and, at the same time, its pointlessness in the long run.

The teachers define graduate studies as a level of higher education largely characterised by various imitations (implementation of educational programmes considering the personnel abilities of the university and its main profile, which leads to a decrease in the share of disciplines forming general professional and professional competencies; a breach in the continuity mechanism between bachelor's and master's programmes, lack of remedial courses, advanced courses, etc.). In connection with the imitation issue in higher school the author considers the attitude that the two main participants of educational process have towards the extramural and online forms of higher education. 
The author concludes about the depth of the imitations issue in higher school, the variety of their forms, and defines the conditions triggering imitations at a university level. Imitations are considered, among other things, as a consequence of the modernisation of higher school.

Keywords: imitation; higher school; educational practices; educational practices imitations; modernisation of education system; graduate studies; extramural form of education; online education; university; teacher; student

\section{REFERENCES}

Bodriiar, Zh. (2015) Simuliakry $i$ simuliatsiia. Moscow, Izdatel'skii dom «POSTUM». 240 p. (In Russ.)

Delez, Zh. (1998) Platon i simuliakr. In: Intentsional'nost' i tekstual'nost'. Filosofskaia mysl' Frantsii XX veka / comp. by E. A. Naiman and V. A. Surovtsev. Tomsk, Vodolei. 320 p. Pp. 225-240. (In Russ.)

Doktorov, B. Z. (2016) Sovremennaia rossiiskaia sotsiologiia: Istoriko-biograficheskie poiski : in 9 vol. / Ed. by B. Z. Doktorov, A. N. Alekseev and E. I. Grigor'eva. CD. Moscow, TsSPiM. 5901 p. (In Russ.)

Zyrianov, V. V. (2017) Podgotovka sotsiologov v universitetakh Rossii na osnove FGOS 3+ v rakurse variativnosti uchebnykh planov. In: Vysshaia sbkola: opyt, problemy, perspektivy. Materialy X Mezbdunarodnoi nauchno-prakticheskoi konferentsii : in 2 parts/ ed. by V. I. Kazarenkov. Moscow, Izd-vo RUDN. Part 1. 497 p. Pp. 225-230. (In Russ.)

Motovilov, O. V. (2016) Problemy podgotovki kadrov v magistrature. Vysshee obrazovanie v Rossii, no. 2 (198), pp. 38-45. (In Russ.) Russ.)

Plaksii, S. I. (2015) Investitsii v obrazovanie. Znanie. Ponimanie. Umenie, no. 3, pp.18-29. (In

Rudakov, V. N., Roshchina, Ia. M. and Bitokova, L. A. (2019) Izmeneniia strategii, motivatsii $i$ ekonomicheskogo povedeniia studentov i prepodavatelei rossiiskikb vuzov. Informatsionnyi biulleten'. Moscow, Natsional'nyi issledovatel'skii universitet «Vysshaia shkola ekonomiki». 84 p. (Monitoring ekonomiki obrazovaniia. № 1 (133)). (In Russ.)

Seliverstova, N. A. (2015) Sotsiologicheskoe obrazovanie: obespechennost' uchebnoi literaturoi i ee kachestvo. Sotsiologicheskie issledovaniia, no. 1, pp. 128-133. (In Russ.)

Seliverstova, N. A. (2019) Opyt metodologicheskoi refleksii issledovaniia imitatsii obrazovatel'nykh praktik v rossiiskoi vysshei shkole. In: II Moiseevskie chteniia: kul'tura kak faktor natsional'noi bezopasnosti Rossii : doklady i materialy Obshcherossiiskoi (natsional'noi) nauchnoi konferentsii, 26 iiunia 2019 g. / ed. by A. V. Kostina and V. A. Lukov. Moscow, Izd-vo Mosk. gumanit. un-ta. 520 p. Pp. 400-404. Publications.mosgu.ru [online] Available at: http://publications.mosgu. $\mathrm{ru} /$ index.php/main/catalog/book/14 (access date: 30.08.2019). (In Russ.).

Senashenko, V. S. and Pykhtina, H. A. (2017) Preemstvennost' bakalavriata i magistratury: nekotorye kliuchevye problem. Vysshee obrazovanie v Rossii, no. 12 (218), pp. 13-25. (In Russ.).

Toshchenko, Zh. T. (2015) Fantomy rossiiskogo obshchestva. Moscow, Tsentr sotsial'nogo prognozirovaniia i marketinga. 668 p. (In Russ.).

Tseli ustoichivogo razvitiia OON $i$ Rossiia. Doklad o chelovecheskom razvitii $v$ Rossiiskoi Federatsii za 2016 g. (2016) / ed. by S. N. Bobyleva and L. M. Grigor'eva. Moscow, Analiticheskii tsentr pri Pravitel'stve RF. 298 p.

Submission date: 30.08 .2019$.

Селиверстова Нина Анатольевна - доктор социологических наук, профессор, профессор кафедры социологии Московского гуманитарного университета. Адрес: 111395, Россия, г. Москва, ул. Юности, д. 5. Тел.: +7 (499) 374-60-21. Эл. адрес: nseliverstova@mosgu.ru

Seliverstova Nina Anatolyevna, Doctor of Sociology, Professor, Professor, Department of Sociology, Moscow University for the Humanities. Postal address: 5, Yunosti St., Moscow, Russian Federation, 111395. Tel.: +7 (499) 374-60-21. E-mail: nseliverstova@mosgu.ru 